less cost. I think it will be admitted that even for an ordinary case 2000 units are practically useless, but still it is sent out in that strength at a price of $2 s, 6 d$. It follows that if one has a case of diphtheria of any degree of severity it is necessary to inject from $20 \mathrm{~s}$. to $30 \mathrm{~s}$. worth of antitoxin in order to hope for success. This might be a matter of no moment to hospital authorities but to the general practitioner who has no hope in many instances of being paid it is of some importance. I trust others will take this matter up in order that the strength of antitoxin will be increased and the price reduced.-I am, Sirs, yours faithfully,
Portsmouth, Feb. 5th, 1906.
R. EMmeTT, M.D. Durh.

\section{HEMPSTEAD CHURCH, ESSEX: THE BURIAL PLACE OF WILLIAM HARVEY.}

To the Editors of THE LANCET.

SIRS, -The church tower of Hempstead, Essex, a smal ${ }^{1}$ village of some 400 inhabitants, fell down in 1882, and the stones still lie in disfiguring heaps in the churchyard. The district is a purely agricultural one and it has hitherto been found impossible to raise locally an amount sufficient for its rebuilding. The parishioners deeply value their privilege of being the custodians of the mortal remains of Dr. William Harrey whose discovery of the circulation of the blood was mainly instrumental in raising the art of medicine and surgery to its present rank as a science. But their means being so small outside help is essential for rebuilding the tower of the church, which is estimated to cost $£ 1500$, and it has occurred to me as the newly appointed vicar of the parish that the members of the medical profession would feel it a privilege to contribute to restore to decency and order the structure in which rests the body of one to whom they owe so much.

I have communicated with the Royal College of Physicians of London and the Royal College of Surgeons of England and these bodies have recognised the justice of my appeal, the former by a contribution of 20 guineas and the latter by one of 10 guineas, provided a sufficient sum for the purpose is raised. May I ask you to use your influence in the matter and to open a subscription list in your journal, asking members of the medical profession at home and abroad to send contributions to Messrs. Barclay, Bankers, Saffron Walden, Hempstead Tower Fund, in honour and to the memory of such an illustrious member of their profession as Dr. William Harvey proved himself to be.

I am, Sirs, yours faithfully,

E. J. ROBERTS, Vicar.

Hempstead Vicarage, Saffron Walden, Feb. 12th, 1906.

The following sums have been already paid or promised :-

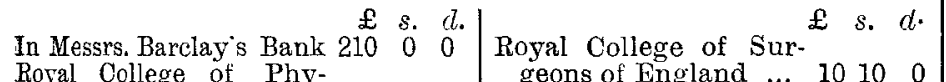

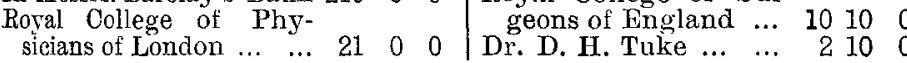

\section{MEDICAL PRACTITIONERS AND THE NOTIFICATION OF INFECTIOUS DISEASES. \\ To the Editors of THE LANCET.}

Sins,--In your issue of Feb. 3rd you reported an action recently brought against Dr. Louis Stamm for alleged negligence in notifying a case of typhoid fever. In commenting upon the action you stated inter alia that the judge ordered the costs to be paid by the plaintiff on the highest scale "so that as far as possible Dr. Stamm will be indemnified for his necessary expenditure in resisting the claim against him." And, further, you stated "he," Dr. Stamm, " had to undergo all the anxiety and expense of preparing his defence."

May I be allowed somewhat to alter such statements by reporting that the case on behalf of Dr. Stamm was carried into court by the Medical Defence Union, and that no part of the expenses and costs incidental to such defence has had to be borne by the defendant, who most wisely had become, some years since, a subscriber to the Union. It is impossible, of course, for the Union to relieve any of its members whilst defending them from some of the anxiety due to such a position, but I think I may safely say that it is inaccurate to state that "all the anxiety" was undergone by the defendant, and certainly none of the expenses fell upon him. The fact that the defence was raised successfully in this action by the Union was reported in the accounts of the case published in the newspapers, but it apparently escaped your editorial notice.

I am, Sirs, yours faithfully,

$$
\text { A. G. BATEMAN, }
$$

\section{4, Trafalgar-square, W.C., Feb. 13th, $1906 . \quad$ General Secretary.}

** We did not know that Dr. Stamm's defence was undertaken by the Medical Defence Union. We congratulate Dr. Stamm on his foresight and once again the Union on its good work.-ED. L.

\section{THE LONDON COUNTY COUNCILLORS IN PARIS.}

(From our Special Sanitary Commissioner.)

Paris, Feb. 10th.

WHEN the 82 members of the London County Council braved the stormy weather and embarked for Calais and Paris they undoubtedly thought that a great reception was awaiting them. This Sir Edwin Cornwall, speaking as chairman of the London County Council at the final banquet, frankly confessed; but, he added, "our expectations have been exceeded a thousand-fold." First of all, it is not usual for members of a municipality to be received with military honours. The Republican Guards, both the horse-guards and infantry, though now under the authority of the Minister of War, were originally a municipal guard and are still employed exclusively for maintaining order within the capital. Thus, when the members of the London County Council reached the Northern station at Paris they found a guard of honour protecting the approaches of the platform and a numerous escort of horse-guards to ride by the side of their carriages and to clear the road in front. Two military bands, one inside and the other outside the station, played the national anthems of the two countries as soon as the councillors arrived and they were, of course, met by their Parisian colleagues. The cavalry escort accompanied the councillors during the whole week and it was not merely the Paris municipality that rendered these honours; the Government also took an active part in the welcome. Not only were the councillors received by the Prime Minister and the Minister of Foreign Affairs, M. Rouvier, but, contrary to the usual custom, he delivered a speech to his visitors expressing his cordial sympathy with their mission. A few minutes previously the President of the Republic, M. Loubet, had made a similar departure from the usual custom, for he favoured his visitors with quite a lengthy address which of course was reproduced by the daily press. Then, finally, M. Dubief, Minister of the Interior, gave the London and Paris councillors a great reception and entertainment at his official residence.

That the representatives of municipal administrations should thus be honoured has, of course, an important political significance. Its meaning is obvious, but it is not the business of this journal to deal with purely political questions. In his speech of welcome Dr. Paul Brousse, President of the Paris Municipal Council, alluded to the many visits and exchanges of courtesies that had recently occurred between the two countries, including that of members of the medical profession on both sides of the Channel. Then he added: "At this very moment these two good neighbours are sitting side by side in the councils of Europe with this common object in view-the maintenance of peace."

Again, in another passage pronounved, be it observed, by a doctor of medicine, the President of the Paris Municipal Council said: "In the great town of Paris, of all our various municipal services I do not know one that can engender any sense of hatred in the minds of the citizens. On the contrary, all leads to concord; education, the measures of solidarity introduced in the schools, poor relief, public health, the creation of easy and agreeable means of transit-all these services are absolutely pacific in their purpose. Those who are successful workers in such pursuits must be admirably prepared to act as propagandists in favour of peace and liberty."

In the face of these remarks and after a week of really extraordinary demonstrations it would be mistaken modesty, leading to a misrepresentation of history, if the medical profession on both sides of the Channel failed to claim a share. 